\title{
Weed Interference Periods in Early Wheat in the Midwest of PARANÁ
}

\author{
Períodos de Interferência de Plantas Daninhas em Trigo Precoce na Região Centro Ocidental \\ Paranaense
}

SILVA, A.A.P. ${ }^{2}$, OLIVEIRA NETO, A.M. ${ }^{3}$, NAIARA, G. ${ }^{4}$, KARPINSKI, R.A.K. ${ }^{2}$, and MACIEL, C.D.G. ${ }^{2}$

\begin{abstract}
Several factors can influence wheat crop yield, they include the interference imposed by weeds is one of the most important. The objective of this study was to evaluate the critical periods of weed interference in early wheat in the midwest of the state of Paraná, Brazil. The experiment was conducted in an experimental area located in Campo Mourão PR, during the year 2013, using the BRS Pardela cultivar. The treatments consisted of periods of coexistence and weed control in wheat. Periods of coexistence and control were $0,7,14$, 28,35 and the whole cycle at days after crop emergence (DAE). Number of reproductive tillers per plant, spike length, number of spikelets per spike, plant height and wheat crop yield, were significantly affected by coexistence with prevailing infestation of Raphanus raphanistrum, therefore, a critical period of interference was determined at 16 to 24 DAE.
\end{abstract}

Keywords: competition, Raphanus raphanistrum, Triticum aestivum.

RESUMO - Vários fatores podem influenciar a produtividade da cultura do trigo, dos quais a interferência imposta pelas plantas daninhas é um dos mais importantes. O objetivo deste trabalho foi avaliar os periodos criticos de interferência das plantas daninhas em trigo precoce na região Centro Ocidental Paranaense. O experimento foi desenvolvido em área experimental localizada em Campo Mourão-PR, durante o ano de 2013, utilizando o cultivar BRS Pardela. Os tratamentos foram constituidos de periodos de convivência e controle das plantas daninhas na cultura do trigo. Os periodos de convivência e controle foram de 0, 7, 14, 28, 35 e o ciclo todo em dias após emergência da cultura (DAE). O número de perfilhos reprodutivos por planta, o comprimento da espiga, o número de espiguetas por espiga, a altura das plantas e a produtividade da cultura do trigo foram significativamente alterados pela convivência com infestação prevalecente de Raphanus raphanistrum, permitindo estabelecer periodo crítico de prevenção da interferência dos 16 aos $24 D A E$.

Palavras-chave: competição, Raphanus raphanistrum, Triticum aestivum.

\section{INTRODUCTION}

Weed infestation is one of the limiting factors to wheat crop yield, evaluation of interference intensity is observed by plant growth reduction and decreased yield. However, competition relations between wheat crops and weeds also depend on other factors, such as weather variations, the populations of the species in the area and crop management practices (Agostinetto et al., 2008). Therefore, the higher the pressure of undesirable species, the greater the competition for resources, as well as the interference in wheat crops. In addition, competition may be even greater if the species are morphologically and physiologically similar, because they will show similar requirements (Pitelli, 1987).

1 Recebido para publicação em 29.6.2015 e aprovado em 6.1.2016.

2 Universidade Estadual do Centro-Oeste, PPGA/UNICENTRO. Guarapuava-PR, Brasil, <andrepazinato0@gmail.com>; ${ }^{3}$ Universidade Federal de Pelotas, UFPEL. Pelotas-RS, Brasil; ${ }^{4}$ Universidade Federal de Santa Catarina, UFSC, Curitibanos-SC, Brasil. 
Weed interference affects wheat productivity, generating an increase in production costs, given the need to adopt control measures. Several weed species cause economic losses for wheat crops; however, in Southern Brazil, ryegrass (Lolium multiflorum) and turnip (Raphanus raphanistrum) are the most important ones (Lamego et al., 2013).

Knowledge of weed species in crop areas and weed infestation periods is crucial for proposing efficient control measures (Fleck et al., 2004; Zanine \& Santos, 2004). In addition, the morphological characteristics of cultivated species are also important, since rapid initial growth of crops, high leaf area index, high interception of photosynthetically active radiation and dry matter production favor the competitive ability of crops (Haefele et al., 2004; Bianchi et al., 2006; Rigoli et al., 2009).

At the beginning of the cycle, crops and weeds can coexist for a certain period without incurring damage to crop productivity. This phase is called the period before interference (PBI), wherein the environment can provide growth of resources required by crops and weeds (Brighenti \& Oliveira, 2011). The other study period starts at emergence and determines the length of time a crop should grow free of the presence of weeds so that its yield is not affected. It is called total period of interference prevention (TPIP). After that time, the existing weeds will not compete in order to reduce wheat yield, because the crop can suppress competing plants (Pitelli, 1987). Finally, there is a third period, referred to as critical period of interference prevention (CPIP), which is the phase in which control practices should be effectively adopted in order to prevent losses in productivity; it is the difference between PBI and TPIP (Evans et al., 2003).

Periods of weed competition against wheat crops can assist in the choice of the type of management and/or control to be used. Knowledge of these periods may reduce the number of herbicide applications, improve control effectiveness and reduce possible environmental contamination and emergence of herbicide-resistant weeds (Agostinetto et al., 2008). However, the degree of interference is strongly influenced by the characteristics of the environment, the weeds and the cultivated species, because determining periods of interference depends on these particular conditions.

Thus, this work was aimed at evaluating the critical periods of weed interference on early wheat crops, cultivar BRS Pardela, in the midwest of the state of Paraná, Brazil.

\section{MATERIAL AND METHODS}

The experiment was conducted in the field between May $9^{\text {th }}$ and September $16^{\text {th }} 2013$, in an area located in the municipality of Campo Mourão-PR. The soil was classified as an Oxisol (Embrapa, 2013). Soil analysis showed pH in water of 6.02 and the following contents: $\mathrm{H}+$ $\mathrm{Al}^{+3}: 5.11 \mathrm{cmol}_{\mathrm{c}} \mathrm{dm}^{-3} ; \mathrm{Ca}^{+2}: 3.47 \mathrm{cmol}_{\mathrm{c}} \mathrm{dm}^{-3}$; $\mathrm{Mg}^{+2}: 1.46 \mathrm{cmol}_{\mathrm{c}} \mathrm{dm}^{-3} ; \mathrm{K}^{+}: 0.46 \mathrm{cmol}_{\mathrm{c}} \mathrm{dm}^{-3} ; \mathrm{P}$ : $5.79 \mathrm{mg} \mathrm{dm}^{-3}$; C: $13.2 \mathrm{~g} \mathrm{dm}^{-3}$; clay, $740 \mathrm{~g} \mathrm{~kg}^{-1}$; silt, $110 \mathrm{~g} \mathrm{~kg}^{-1}$; and total sand, $150 \mathrm{~g} \mathrm{~kg}^{-1}$. According to the Köppen method, the climate is classified as CFA, characterized by subtropical climate (IAPAR, 2008). Figure 1 shows the weather conditions during the experiment. Cumulative rainfall rate was $661.5 \mathrm{~mm}$, and average minimum and maximum temperatures were 11.4 and $30.2{ }^{\circ} \mathrm{C}$, respectively.

Because the weather was frosty on the $24^{\text {th }}$ and the $25^{\text {th }}$ of July, the experiment was covered with black plastic canvas to minimize weather damage. The cover was placed at 5:00 $\mathrm{pm}$ on the days before the frost and removed at 6:30 in the morning, before sunrise.

Two weeks before sowing, the weeds were desiccated by applying glyphosate $+2,4-\mathrm{D}$ $\left(2,160+1,209 \mathrm{~g} \mathrm{ha}^{-1}\right)$ to eliminate the weeds and, thus, standardize crop emergence. BRS Pardela (early cycle) was the wheat cultivar of choice. Sixty seeds were sown per meter, inter-spaced at $0.17 \mathrm{~m}$. Fertilization was defined based on the interpretation of soil analysis, following the recommendations for wheat (IAPAR, 2013). Thus, they were applied $165 \mathrm{~kg} \mathrm{ha}^{-1}$ formulated 8-20-20 (NPK). The topdressing was held in early tillering stage, using $60 \mathrm{~kg} \mathrm{~N}$ per ha-1, in the form of urea.

The experiment had a randomized block design in a $2 \times 6$ factorial arrangement, with 


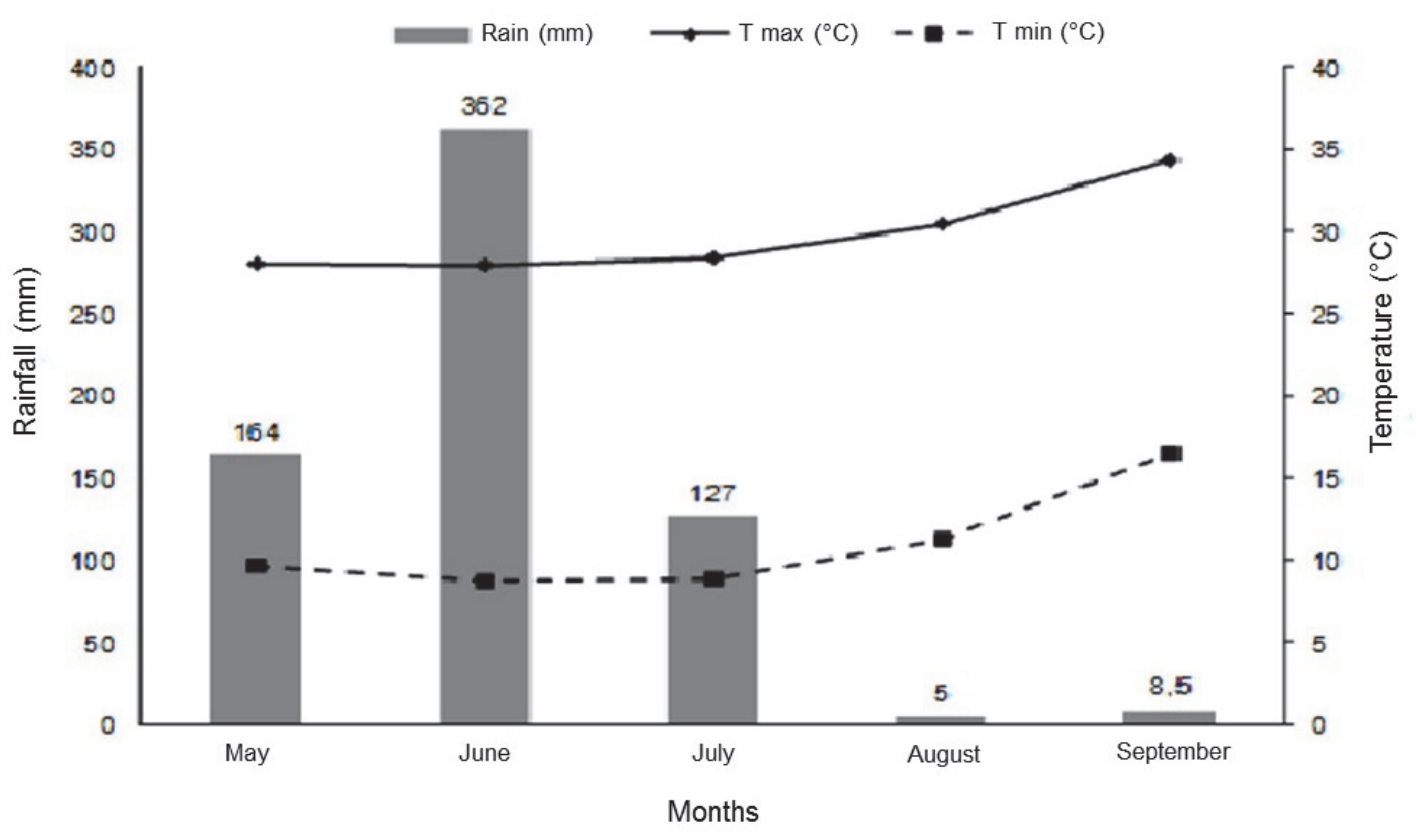

Figure 1 - Rainfall $(\mathrm{mm})$ and mean minimum and maximum temperatures $\left({ }^{\circ} \mathrm{C}\right)$ between May $9^{\text {th }}$ to September $16^{\text {th }}$, 2013. Campo Mourão, PR, 2013.

four replicates. On the first factor, the periods of cohabitation (PBI) and weed control (TPIP) were evaluated. The second factor consisted of weed management times $(0,7,14,28,35$ and the whole cycle). Each experimental unit occupied an area of $11,2 \mathrm{~m}^{2}(2.80 \times 4.00 \mathrm{~m})$.

The weeds that emerged after the control intervals (TPIP) were no longer controlled. Weeds were eliminated by hoeing between the rows and weeding in the rows. The predominant species in the experimental area was the turnip ( $R$. raphanistrum).

Pests and diseases were monitored throughout the experimental period, control measures where adopted when necessary. The choice of insecticides and fungicides, as well as the applied rates, followed the technical recommendations for wheat crops (IAPAR, 2013).

At the end of each period, shoot dry matter (SDM) and density were determined for $R$. raphanistrum by using a square template with inner area of $0.25 \mathrm{~m}^{2}$. The template was thrown randomly on the useful area of the parcel; the weeds were counted, collected and packed in paper bags. The samples were dried in a forced-air oven at $60{ }^{\circ} \mathrm{C}$ until constant mass. At the end of the crop cycle, height of wheat plants, number of viable tillers per plant, spike length and number of spikelets per spike were measured, randomly, in ten plants per plot. Grain yield was determined from the manual harvest of $2 \mathrm{~m}^{2}$ in the center of the plot. For standardization, grain moisture was adjusted to $130 \mathrm{~g} \mathrm{~kg}^{-1}$.

The results were submitted to analysis of variance by the $\mathrm{F}$-test and non-linear regression analysis, at $5 \%$ probability $(\mathrm{p}<0.05)$. The mathematical models chosen were those which best explain the biological behavior of the phenomenon. To determine the period before interference (PBI), the total period of interference prevention (TPIP) and the critical period of interference prevention (CPIP), productivity losses were estimated at $5 \%$; the weed-free treatment was used as a reference. The losses were estimated by using nonlinear regression equations for coexistence and control periods.

\section{RESULTS AND DISCUSSION}

The species $R$. raphanistrum showed great adaptative ability, as it had polynomial gains of SDM even after plant population was reduced (Figure 2). The reduction in the number of turnip plants can be associated with wheat 


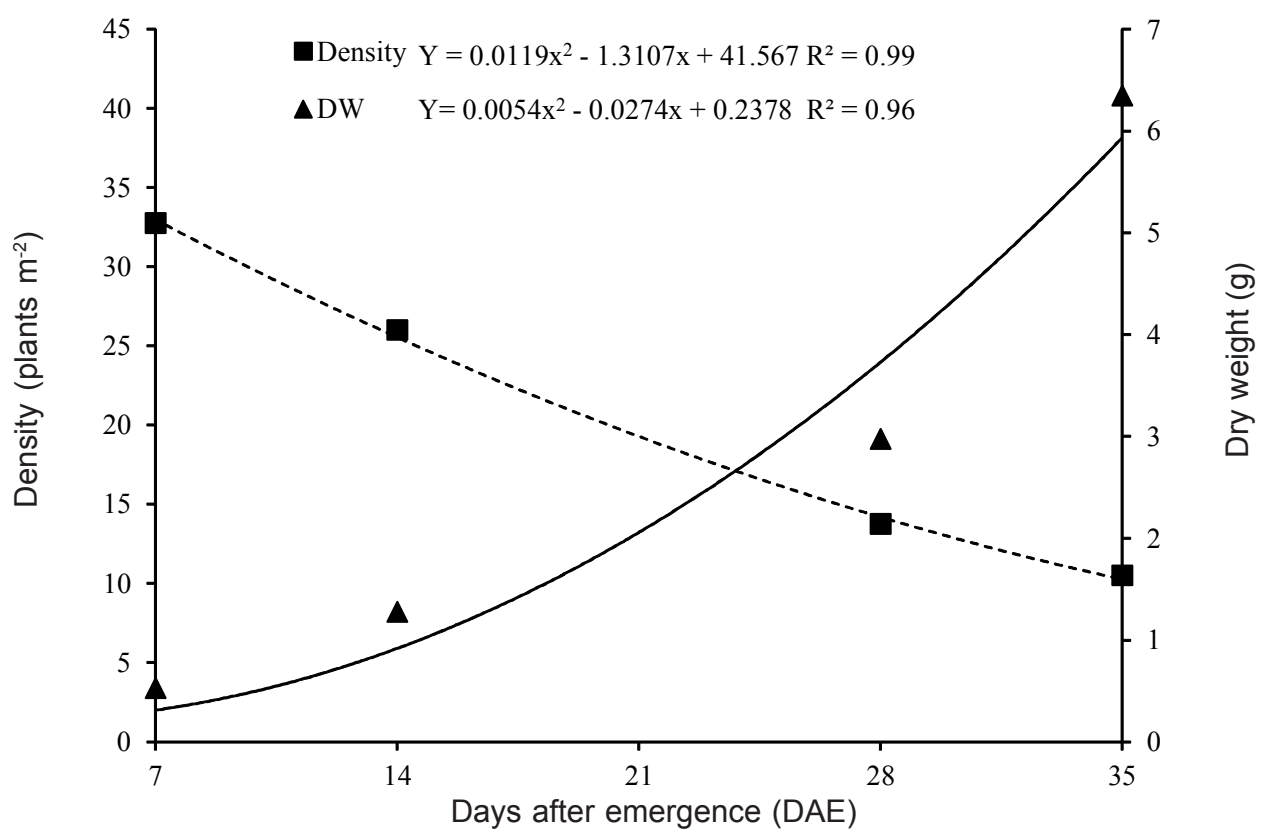

Figure 2 - Density (plants $\mathrm{m}^{-2}$ ) and shoot dry mass of turnip (R. raphanistrum). Campo Mourão, Paraná, 2013.

canopy closure at the rows, which decreased the incidence of light and caused plant density adjustment depending on the availability of this resource (Green-Tracewicz et al., 2012).

According to Radosevich et al. (1997), with population increase and weed development, especially weeds that germinated and emerged at the beginning of the cycle, there is more intense inter- and intraspecific competition, so that taller weeds become dominant, whereas shorter ones are removed or die, also by the crop itself. Hucl (1997) stated that the tillering capacity of wheat cultivars is extremely important in competition against weeds. In this sense, the cultivar BRS Pardela stood out for good initial tillering and plant height, which may have contributed to reduction in the density of $R$. raphanistrum (Figures 3 and 6).

There was a reduction in the number of viable tillers per plant as the coexistence period progressed (Figure 3). In other words, the coexistence between the crop and the weeds has significantly reduced the number of tillers/spike per clump. When the control period was analyzed, it was seen that the number of reproductive tillers became steady after $28 \mathrm{DAE}$. According to Almeida \& Mundstock (2001), emission, development and survival of tillers in plant communities are modified the quality of light. However, to ensure the quality of spikes and grains during weed competition, wheat decreases the emission of tillers or aborts the existing ones (Agostinetto et al., 2008).

The coexistence period interfered in spike length, and this feature was reduced as coexistence continued, reaching the minimum size of $13.96 \mathrm{~cm}$ at $30 \mathrm{DAE}$ (Figure 4). For the control period, when there was no coexistence between the wheat crop and the turnip for $29 \mathrm{DAE}$, spike length was not affected, and reached $16 \mathrm{~cm}$.

There was the lowest number of spikelets per spike when the wheat coexisted with the turnip for more than 30 DAE (Figure 5). By contrast, a 35 day control period was enough to ensure the highest number of spikelets per spike. These results show that the weed $R$. raphanistrum is quite aggressive in the competition against the wheat crop, significantly reducing important yield components, such as number of spikes per plant, spike length and number of spikelets per spike.

In a way, these results were expected, because a longer coexistence period leads to greater competition for essential production 


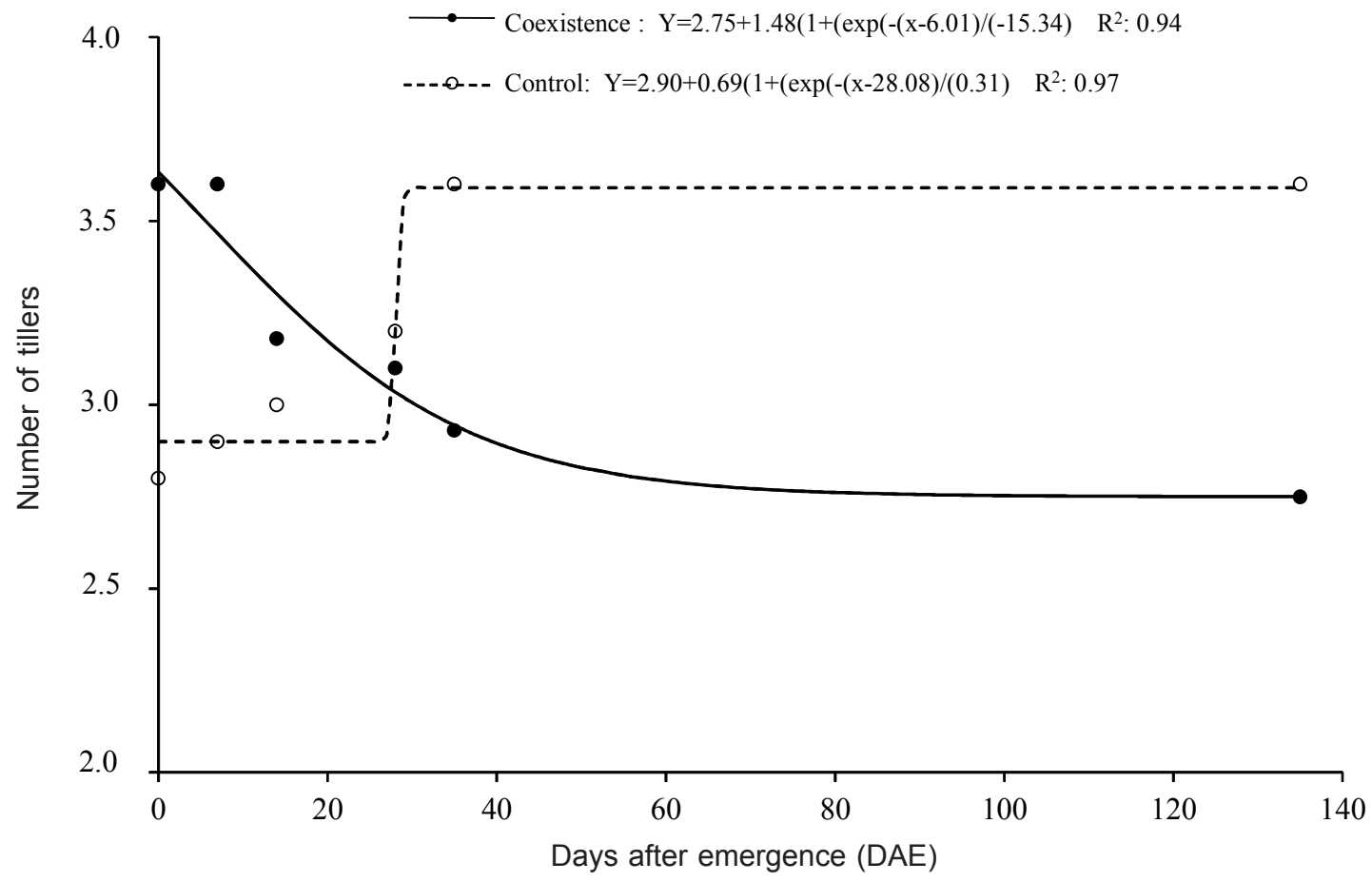

Figure 3 - Number of reproductive tillers per wheat plant in accordance with the periods of coexistence and weed control. Campo Mourão, Paraná, 2013.

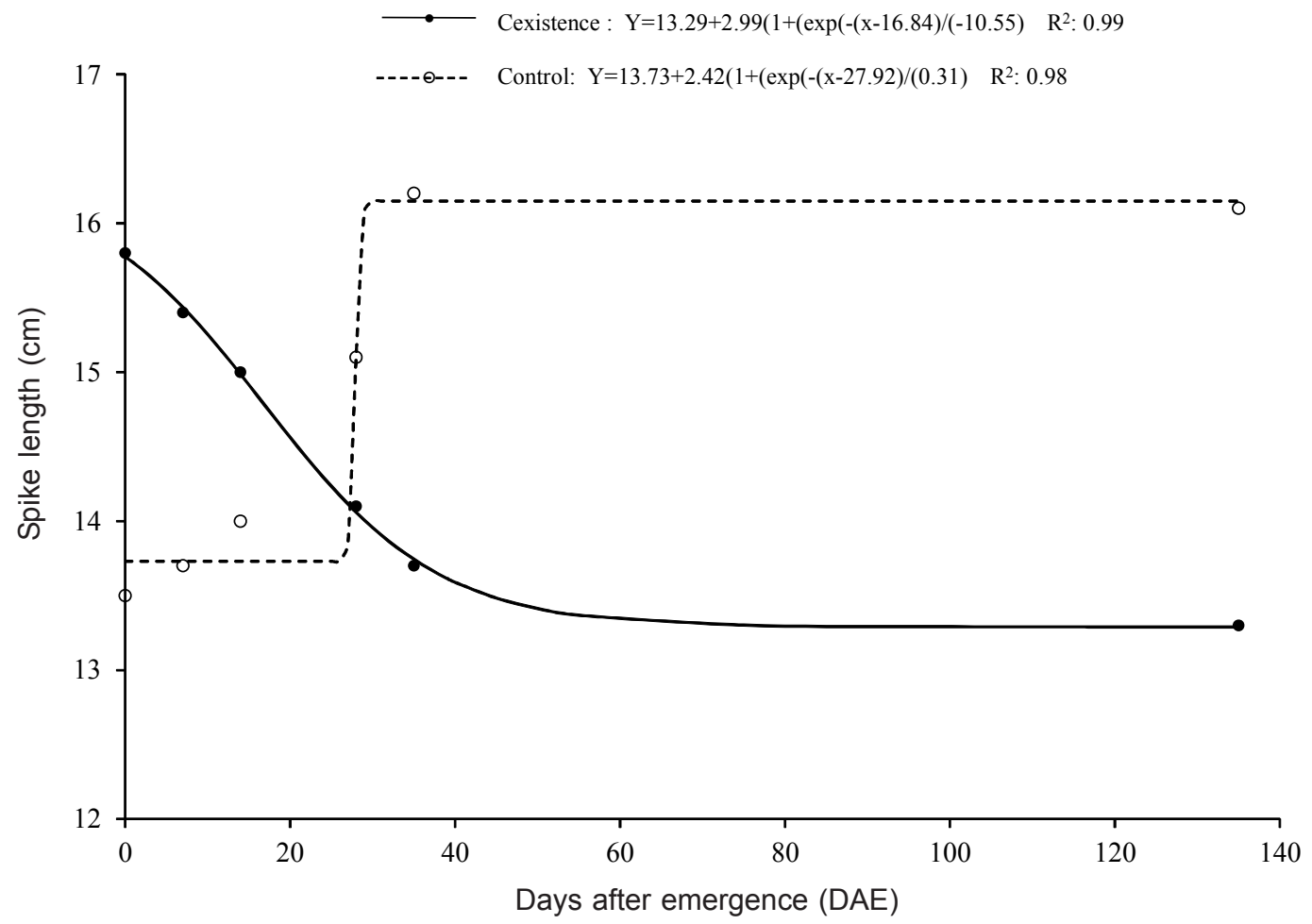

Figure 4 - Wheat spike length in accordance with the periods of coexistence and weed control. Campo Mourão, PR, 2013. 


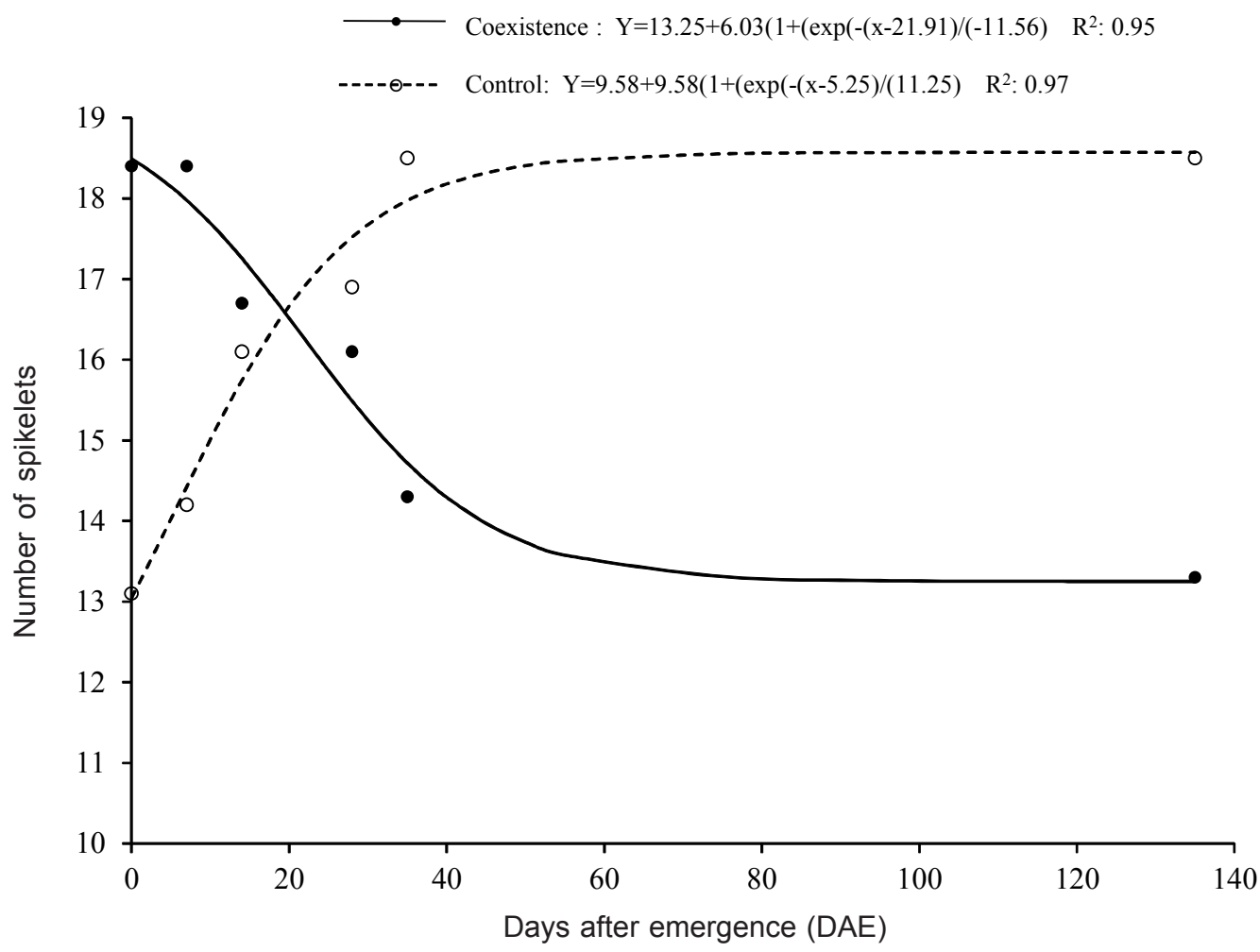

Figure 5 - Number of spikelet per spike of wheat in accordance with the periods of cohabitation and weed control. Campo Mourão, Paraná, 2013.

resources, e.g., water, light, nutrients and physical space. This intensification directly compromises the primary process of energy production, namely, photosynthesis, leading to reduced assimilate production. Under these conditions, the wheat can not meet the energy demand of yield components, leading to abortion and underdevelopment (Floss, 2011).

The plant height variable was also hampered by competition against the turnip (Figure 6). This weed has affected plant height since the second week of coexistence, while in the control period, at about $24 \mathrm{DAE}$, plant size was stable. After that period, the wheat crop could inhibit interference from weed growth. Thus, plant height can be significantly affected by weeds, depending on the particular crop and the growth habit of the weeds, thus reducing light penetration in the canopy and causing productivity losses (Fleck et al., 2007). Therefore, tall wheat plants are indicative of good competition capacity against weeds.

The greater height can provide a denser canopy, which may result in adequate soil cover and reduce light penetration between the rows, avoiding weed occurrence. Consequently, taller plants show greater competitiveness against weeds because they have more advantage in light interception (Rigoli et al., 2009).

The experimental units where the wheat crop was kept in initial growth periods in the absence of weeds allowed to calculate the period during which weeds may emerge and infest the culture without any loss in productivity. It took 16 days for wheat to show significant losses (5\%) of productivity (Figure 7), a period that corresponds to the PBI. For the PTIP, it took 24 DAE, which shows that weed control must be performed up to that amount of days; after that, the crop is more competitive than the weeds. Thus, the period when the practices for control of $R$. raphanistrum should be effectively adopted (CPIP) for the midwest of Paraná ranges between 16 and 24 DAE.

These PBI and PTIP values were very similar to those estimated by Agostinetto et al. 


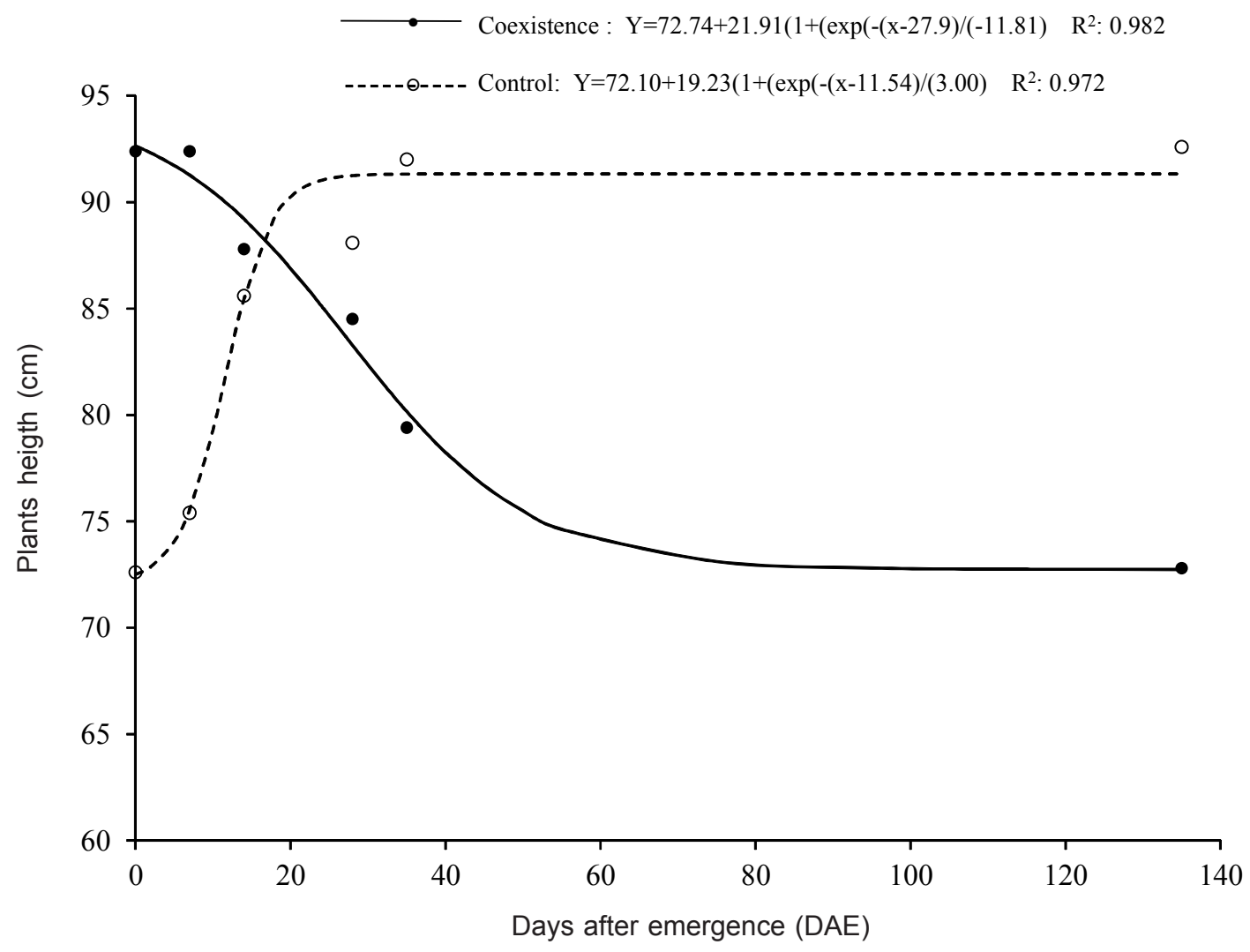

Figure 6 - Wheat plant height based on the periods of coexistence and weed control. Campo Mourão, Paraná, 2013.

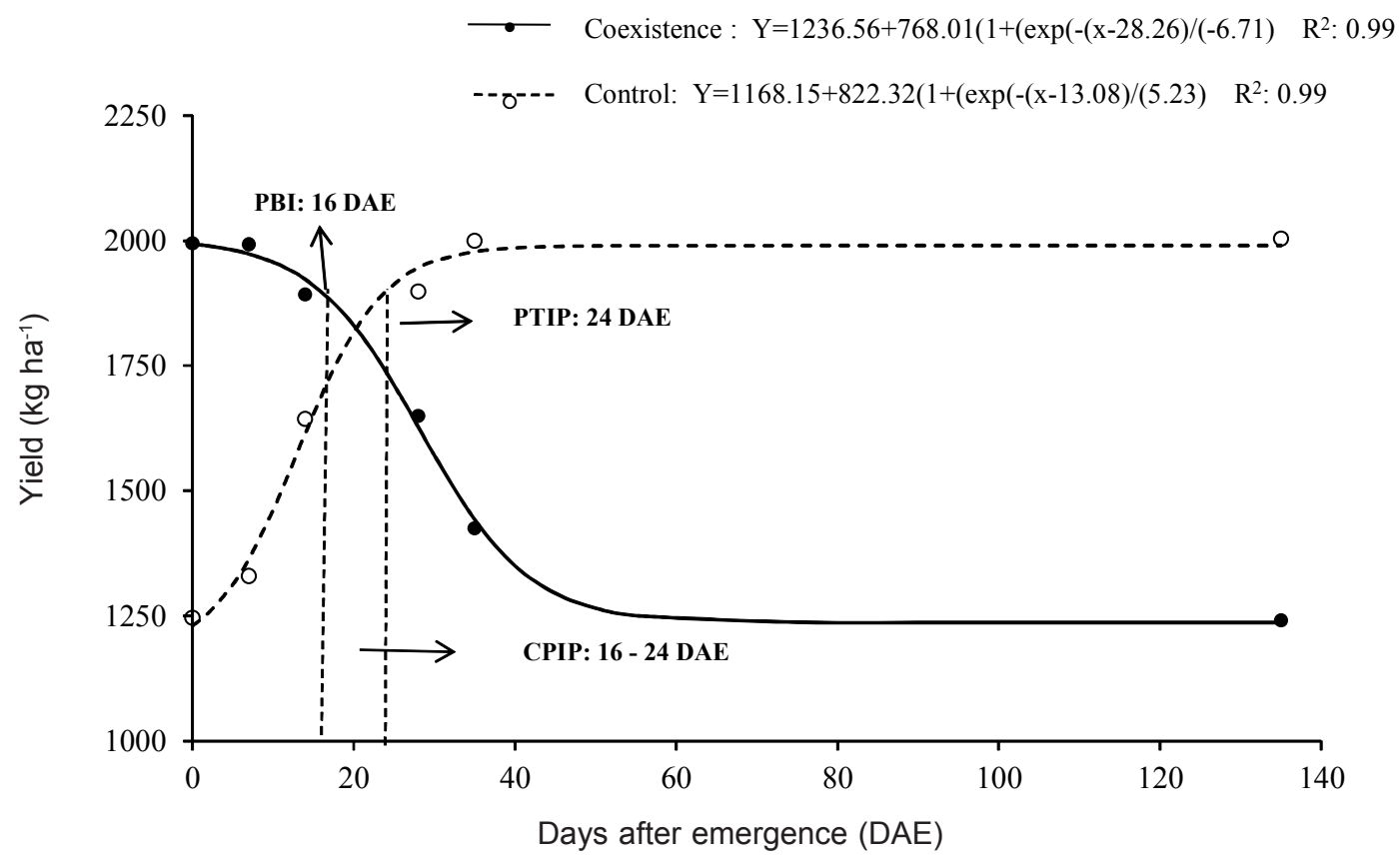

Figure 7 - Wheat grain yield based on the periods of coexistence and weed control. Campo Mourão, Paraná, 2013. 
(2008), which were 12 and 24 DAE for PBI and PTIP, respectively, in na area with infestation of turnip and ryegrass, for the cultivar FUNDACEP 52, early to medium cycle, grown in the municipality of Capão do Leão-RS. However, they differ from those reported by Zagonel \& Fernandes (2010), who stated that control should be held up to $32 \mathrm{DAE}$ to avoid wheat crop yield reduction.

For proper weed management, determining the CPIP is crucial in order to avoid losses and/ or unnecessary use of herbicides. However, climate, crop, weeds and management may influence the results, leading to differences in different places and years, which reinforces the importance of regionalization of studies. In general, number of reproductive tillers per plant, spike length, number of spikelets per spike and wheat plant height were significantly altered by coexistence with $R$. raphanistrum plants.

For the midwest of the state of Paraná, in the municipality of Campo Mourão, in an area with prevailing infestation of $R$. raphanistrum, the critical period for interference prevention for the early wheat cultivar BRS Pardela was established between 16 and 24 DAE.

\section{LITERATURE CITED}

AGOSTINETTO, D. et al. Período crítico de competição de plantas daninhas com a cultura do trigo. Planta Daninha, v. 26, n. 2, p. 271-278, 2008.

ALMEIDA, L. A.; MUNDSTOCK, C. M. A qualidade da luz afeta o afilhamento em plantas de trigo, quando cultivadas sob competição. Ci. Rural, v. 31, n. 3, p. 401-408, 2001.

BIANCHI, M. A. et al. Características de plantas de soja que conferem habilidade competitiva com plantas daninhas. Bragantia, v. 65, n. 4, p. 623-632, 2006.

BRIGHENTI, A. M.; OLIVEIRA, M. F. Biologia de plantas daninhas. In: OLIVEIRA JR, R. S. et al. Biologia e manejo de plantas daninhas. Curitiba - PR: Ominipax, 2011. 348 p.

EMPRESA BRASILEIRA DE PESQUISA

AGROPECUÁRIA - EMBRAPA. Centro Nacional de Pesquisa de Solo. Sistema brasileiro de classificação de solos. 3.ed. Rio de Janeiro: 2013. 353 p.

EVANS, S. P. et al. Nitrogen application influences the critical period for weed control in corn. Weed Sci., v. 51, n. 1, p. $408-417,2003$.

Planta Daninha, Viçosa-MG, v. 34, n. 2, p. 291-298, 2016
FLECK, N.G. et al. Interferência de picão-preto e guanxuma com a soja: efeitos da densidade de plantas e época relativa de emergência. Ci. Rural, v. 34, n. 1, p. 41-48, 2004.

FLECK, N.G. et al. Resposta de cultivares de soja à competição com cultivar simuladora da infestação de plantas concorrentes. Sci. Agric., v. 8, n. 3, p. 213-218, 2007.

FLOSS, E. L. Fisiologia das plantas cultivadas: O estudo do que está por trás do que se vê. Passo Fundo: Universidade de Passo Fundo, 2011. 734 p.

GREEN-TRACEWICZ, E.; PAGE, E. R.; SWANTON, C. J. Light quality and the critical period for weed control in soybean. Weed Sci., v. 60, n. 1, p. 86-91, 2012.

HAEFELE, S. M. et al. Field screening of diverse rice genotypes for weed competitiveness in irrigated lowland ecosystems. Field Crops Res., v. 88, n. 1, p. 39-56, 2004.

HUCL, P. Response to weed control by four spring wheat genotypes differing in competitive ability. Canadian J. Plant Sci., v. 78, n. 1, p. 171-173, 1997.

INSTITUTO AGRONÔMICO DO PARANÁ - IAPAR. Cartas climáticas básicas do estado do Paraná. Londrina: 2008.

IAPAR - Instituto Agronômico do Paraná. Informações Técnicas para o Trigo e Triticale - Safra 2013. Reunião da Comissão Brasileira de Pesquisa de Trigo e Triticale, Londrina - PR. 220p. 2013.

LAMEGO, F. P. et al. Habilidade competitive de cultivares de trigo com plantas daninhas. Planta Daninha, v. 31, n. 3, p. 521-531, 2013.

PITELLI, R. A. Competição e controle das plantas daninhas em áreas agrícolas. Série Técn. IPEF, v. 4, n. 12, p. 1-24, 1987.

RADOSEVICH, S.; HOLT, J.; GHERSA, C. Weed ecology: implications for vegetation management. 2.ed. New York: Wiley, 1997. 589 p.

RIGOLI, R. P. et al. Potencial competitivo de cultivares de trigo em função do tempo de emergência. Planta Daninha, v. 27, n. 1, p. 41-47, 2009.

ZAGONEL, J.; FERNANDES, E. C. Plantas daninhas em trigo: quando controlar. Cult. Grandes Cult., v. 12, n. 1, p. 26-28, 2010.

ZANINE, A. M.; SANTOS, E. M. Competição entre espécies de plantas: uma revisão. Rev. FZVA, v. 11, n. 1, p. 10-30, 2004. 